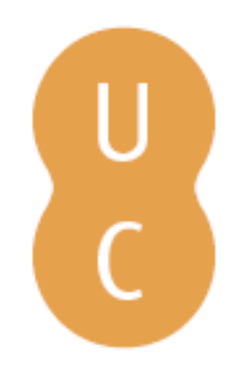

\title{
pombalina
}

\section{Herculano, o rei e o amigo do rei: a polêmica sobre a confederação dos tamoios}

Autor(es): $\quad$ Ribeiro, Maria Aparecida

Publicado por: Imprensa da Universidade de Coimbra

URL

persistente:

URI:http://hdl.handle.net/10316.2/38695

DOI:

DOI:http://dx.doi.org/10.14195/978-989-26-1164-8_18

Accessed : $\quad$ 26-Apr-2023 13:46:40

A navegação consulta e descarregamento dos títulos inseridos nas Bibliotecas Digitais UC Digitalis, UC Pombalina e UC Impactum, pressupõem a aceitação plena e sem reservas dos Termos e Condições de Uso destas Bibliotecas Digitais, disponíveis em https://digitalis.uc.pt/pt-pt/termos.

Conforme exposto nos referidos Termos e Condições de Uso, o descarregamento de títulos de acesso restrito requer uma licença válida de autorização devendo o utilizador aceder ao(s) documento(s) a partir de um endereço de IP da instituição detentora da supramencionada licença.

Ao utilizador é apenas permitido o descarregamento para uso pessoal, pelo que o emprego do(s) título(s) descarregado(s) para outro fim, designadamente comercial, carece de autorização do respetivo autor ou editor da obra.

Na medida em que todas as obras da UC Digitalis se encontram protegidas pelo Código do Direito de Autor e Direitos Conexos e demais legislação aplicável, toda a cópia, parcial ou total, deste documento, nos casos em que é legalmente admitida, deverá conter ou fazer-se acompanhar por este aviso.

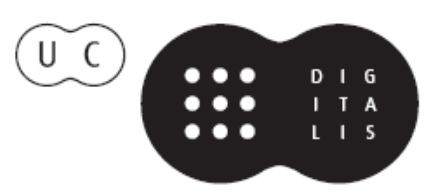


Maria Aparecida Ribeiro

Universidade de Coimbra / Centro de Literatura Portuguesa

\section{HERCULANO, O REI E O AMIGO DO REI: \\ A POLÊMICA SOBRE A CONFEDERAÇÃO DOS TAMOIOS}

1. Uma das preocupações do Imperador Pedro II foi conferir uma identidade à nação brasileira. A começar pelo seu próprio manto - que unia o veludo e o arminho europeus às estrelas do céu do Brasil e à murça com penas do tucano indígena - passando pelo cacau, pelos ramos de café e de tabaco nos seus trajes de gala, até chegar à literatura, à pintura, à música, tudo deveria receber a cor local. Nosso segundo Pedro encomendou a Vítor Meireles, que estudava pintura na França às expensas do governo brasileiro, o quadro "A Primeira Missa no Brasil”. Foi também com o seu patrocínio que Domingos José Gonçalves de Magalhães - considerado o introdutor do Romantismo no Brasil, não só pelo que escrevera na revista Nitheroy, publicada em Paris, em 1836, como pelo livro de poemas Suspiros Poéticos e Saudades, lançado no mesmo ano e na mesma cidade - editou o poema épico A Confederação dos Tamoios, anunciado pelo próprio autor desde suas primícias poéticas.

Composto descontinuadamente durante sete anos e saído em 1856, no Rio de Janeiro, pela Tipografia de Paula Brito, numa edição de luxo, o poema foi elogiado pelos amigos do poeta, antes de vir a lume (cf. Castello, 1953: XIII). Uma vez lançada, a obra recebeu a mais acirrada crítica de José de Alencar, então um jovem romancista com apenas dois livros: no Diário do Rio de Janeiro, sob o pseudônimo de IG, as duas primeiras letras de Iguaçu, a heroína do poema de Magalhães, ele publicou oito cartas (de 10 de junho a 15 de agosto de 1856) que 
foram respondidas, pelo próprio D. Pedro II e por outras personalidades ${ }^{1}$. Pelo que se depreende, o Imperador andou pedindo a opinião de nomes famosos, para lançar o livro ou para tentar melhorar diante do público a reputação de Magalhães como poeta. Entre essas figuras, esteve Alexandre Herculano, cuja crítica, datada de 6 de dezembro de 1856, não foi publicada, a pedido do próprio escritor ${ }^{2}$. E por quê? Para se discutirem as razões do autor de Eurico, será necessário examinar as cartas de Alencar, passando também pelas de Pedro II e pelas daqueles que saíram em defesa do autor d'A Confederação dos Tamoios.

\section{A Confederação e a crítica}

\subsection{Um gênero válido?}

Formado dentro do Neoclassicismo, Magalhães jamais dele se libertou, apesar de, na esteira de Denis e a convite deste, haver lançado as bases da literatura brasileira, na conferência que proferiu em Paris, em 1834, no Instituto Histórico de França, sob o título "Discurso sobre a História da Literatura do Brasil" onde, ao mesmo tempo que focava a importância da literatura como preservadora da memória de um povo, sugeria a recuperação das tradições dos índios (Magalhães, 1974: 12). Na edição d'A Confederação saída em 1864, Gonçalves de Magalhães explica o porquê de haver utilizado o hendecassílabo livre, mas nunca menciona a razão pela qual elegeu o poema épico, ele que, afinal, assumia o lugar de

\footnotetext{
1 Pedro II assinou-se "Outro amigo do poeta". As demais figuras eram Manuel de Araújo Porto Alegre, companheiro de Magalhães em Paris e co-organizador da revista Nitheroy, Frei Francisco de Monte Alverne, que havia sido professor de Magalhães, e Omega, talvez Pinheiro Guimarães. Houve ainda uma série de publicações "a pedido", assinadas por "O boqui-aberto" e "O inimigo das capoeiras", e que, como chama a atenção José Aderaldo Castello (Castello, 1953: 117 n.20), documentam apenas a agressividade da polêmica e o desvirtuamento de seu sentido cultural.

2 Como não foi possível localizar a carta de Pedro II a Herculano e este diz que responde com muito atraso, não se sabe se o Imperador lhe teria escrito antes da polêmica, à espera de uma recensão, por exemplo, ou no calor as discussões, para obter um aliado. A verdade é que A Confederação dos Tamoios foi difundida através de caminhos diplomáticos, através de ofícios expedidos ao Enviado Extraordinário e Ministro Plenipotenciário do Brasil no Uruguai, conselheiro José Maria do Amaral, ao Encarregado de Negócios do Brasil na Espanha, Francisco Adolfo de Varnhagen, ao Príncipe de Wied e Neuwied, com oferencimento em francês, ao Encarregado de Negócios do Brasil na Confederação Argentina e Estados de Buenos Aires, Joaquim Tomás do Amaral, ao Ministro Plenipotenciário do Brasil em Portugal, Conselheiro Antônio Peregrino Maciel Monteiro, ao Conselheiro José Marques Lisboa e ao Dr. Caetano Lopes de Moura, em Paris, assim como a Ferdinand Denis.
} 
introdutor do Romantismo no Brasil e que procurava seguir as orientações de Ferdinand Denis, cuja obra, desde $1824^{3}$, contava já um romancezinho com cenário e personagens brasileiras. No entanto, o verso havia sido recusado por Alencar, que dizia não servir para celebrar os índios e as tradições selvagens da América a forma pela qual Homero cantou os gregos, as desgraças de Tróia e os combates mitológicos. Perguntava IG se não haveria "no caos incriado do pensamento humano, uma nova forma de poesia, um novo metro de verso" (Alencar, 1994b: 170). Mas, ainda que com nova forma, Alencar falava em poema épico nacional: "Escreveríamos um poema, mas não um poema épico; um verdadeiro poema nacional, onde tudo fosse novo, do pensamento até a forma, desde a imagem até o verso" (Alencar, 1994b: 170)4 .

Já Herculano ia mais longe: recusava a epopeia, mas por outra razão que não apenas a sua visão de romântico, evidente quando afirma que os povos bárbaros e primitivos tinham todos a sua poesia e que cumpria "não a vasar em moldes estranhos; não a fundir com as reminiscências da poesia greco-latina" (Herculano, 1986: 215). Em primeiro lugar, dizia ele não acreditar em epopeia nas nações "transformadas, polidas, argumentadoras, voluptuosas, incrédulas da velha Europa" (Herculano, 1986: 215), e comentava que os heróis épicos e a própria epopeia foram perdendo grandeza, de Homero a Virgílio, deste a Tasso, a Dante e a Camões, embora fossem ainda um canto de crente para crentes, assim como o Paraíso Perdido e a Messíada. E, se assim era na Europa, para Herculano, a epopeia tinha ainda menos razão de ser na América, pois as relações entre povos autóctones e colonizadores outras não haviam sido que as de "guerra e extermínio". Por isso, os conquistadores só herdariam dos conquistados os "haveres materiais"; nunca as "tradições", as "saudades", os "afectos colectivos", onde estaria colocada a poesia épica (Herculano, 1986: 215). Mesmo Estácio de Sá, Mem de Sá e outros da mesma estirpe foram "caracteres mais ou menos valorosos", mas estavam longe de poderem ser transformados em personagens

\footnotetext{
3 Trata-se de "Les Maxakalis", incluído nas Scènes de la Nature sous les Tropiques.

${ }_{4}^{4}$ A leitura das Cartas mostra que Alencar, além de exercer a crítica e o magistério, tinha em mente essa nova forma. Trata-se do que o autor chama "um desses amores poéticos e inocentes, que tem o céu por dossel, as lianas verdes por cortinas, a relva do campo por divã" (Alencar, 1994b: 172) e, depois, denomina "epopeias do coração", "epopeia de sentimento e abnegação" (Alencar, 1994a: 66 e 236). O Guarani, que ele assim classifica, começaria a ser publicado logo a 1 de janeiro do ano seguinte (1857) e era a primeira demonstração de que suas ideias poderiam ser executadas. A ele suceder-se-ia Iracema, lenda do Ceará (1865), com um projeto épico ainda mais evidente.
} 
épicas 5 . E acrescentava uma estranha observação, onde mostrava ignorar por completo a miscigenação operada pelos portugueses no Novo Mundo: "Entre o povo brasileiro e os aborígenes do Brasil falta a identidade de sangue, de língua, de religião, de costumes $^{6}$; falta tudo o que constitui a unidade nacional na sucessão dos tempos." Empolgado, ia mais longe — " “...] os brasileiros são europeus na América." (Herculano, 1986: 215) - e acabava por reafirmar o seu conceito de nação - o de divisão política”: "Na minha opinião, as eras heroicas e as gerações épicas do Brasil ficariam sendo as do primitivo Portugal, se uma raça, outrora única, não constituísse hoje duas nacionalidades distintas" (Herculano, 1986: 215).

Aos motivos para recusar-se a fazer a crítica (ou talvez o elogio da Confederação dos Tamoios, como o quereria D. Pedro II), Herculano acrescentava ainda outro que, embora discutível por circunscrever o público apreciador de uma obra aos compatriotas de seu autor, parecia querer atenuar o comentário ao "péssimo efeito" das "frases baixas e triviais", que apontava em quantidade no texto de Gonçalves de Magalhães, mas que ia ao encontro, mais uma vez, dos defeitos apontados por Alencar:

Pelo que respeita às formas externas do poema, recai aí outra dúvida [...] Pode sempre o estrangeiro avaliar bem a frase, as comparações, a verdade descritiva de um poema? Creio que não. Embora a língua seja idêntica entre dois povos, há locuções que num país se tornaram plebeias, e que noutro são elevadas ou pelo menos toleráveis. Na Confederação dos Tamoios há frases, que, quando muito, se poderiam tolerar (em Portugal) na poesia herói-cômica, ou num desses romances-poemas do gênero Orlando Furioso ou de D. Branca (Herculano, 1986: 218).

Na discussão com Alencar sobre a validade ou não de haver Magalhães escolhido a epopeia, a defesa de Araújo Porto-Alegre, que se assina "O amigo

5 Certamente, Herculano ignorava o De Gestis Mendi de Saa, da autoria de José de Anchieta, publicado em Coimbra, no ano de 1563, por Francisco de Sá, filho de Mem de Sá, na oficina de João Álvares, tipógrafo Régio.

6 Sublinhado nosso.

7 Na História de Portugal, rompendo com a tradição que ligava os portugueses aos lusitanos, ele afirmava ser a nação portuguesa um produto político, resultado da formação de um estado pelos barões de um condado situado no noroeste da península. 
do poeta", faz uma afirmação quando muito curiosa, que acaba por dar razão ao crítico cearense e lhe suscita uma crítica certeira ${ }^{8}$ :

O Sr. Magalhães não compôs uma epopeia; fez um poema como outro qualquer; no plano de sua obra não entraram as dimensões colossais do poema épico, mas sim aquelas que são consentâneas com o fragmento da história pátria que se dignou ilustrar com os dons da poesia (Porto-Alegre, in Castello, 1953: 66).

\subsection{Um assunto aceitável?}

A Confederação dos Tamoios tem por tema a primeira - e única - grande união indígena contra os portugueses e vem na esteira de outro poema épico - O Uraguay, onde os índios já apareciam como vítimas, embora no poema de Magalhães, haja uma mudança de ponto de vista que implica também mudança na eleição do herói: este deixa de ser português e passa a ser índio. É Aimbiré, um tamoio do litoral sudeste brasileiro, chefe da luta contra os portugueses de quem foi escravo, assim como seu pai, cuja morte, "sem honras de guerreiro" (Magalhães, $\left.{ }^{3} 1994: 56\right)^{9}$, junto com todas as outras impostas à sua raça, ele quer lavar em sangue.

São justamente as invectivas contra a cobiça portuguesa, contidas em Os Maxakalis e n'O Uraguay, poema menos prestigiado por Ferdinand Denis ${ }^{10}$, mas onde, em 1769, Basílio da Gama pusera na boca de um herói índio, Cacambo, o desabafo "Gentes de Europa, nunca vos trouxera / O mar e o vento a nós" (II, 171-174) e tematizara a escravização dos índios e os abusos sofridos por suas mulheres, que vão encontrar eco em A Confederação dos Tamoios. Aliás, é d' O Uraguay, duma parte fraca, que Magalhães vai recortar a apresentação de seu índios: Aimbiré, Pindobuçu, Jagoanharo, Araraí, Coaquira, aparecem num desfile e com roupas semelhantes aos índios de Basílio (cf. Magalhães³, 1994: 50-53).

8 "O que mais admira é a contradição em que estão os defensores do poema; quando respondem à censura que se faz por carência absoluta do elemento grandioso, dizem que $A$ Confederação dos Tamoios não é uma epopeia; quando se lhes faz notar a falta de imagens e de sentimentos, retrucam que isso são lirismos impróprios de uma obra grave e séria"(Alencar, 1994b: 216).

9 As indicações, apesar de se tratar de um poema épico, não serão feitas por cantos, estâncias e versos, uma vez que a edição usada não os numera.

10 O francês dava mais ênfase ao Caramuru. 
O assunto escolhido para $A$ Confederação dos Tamoios, por ser "tirado dos primeiros tempos coloniais do Brasil" tem plena aprovação de José de Alencar (1994: 157), que, aliás, irá basear-se na mesma época histórica, para construir O Guarani e Iracema. Por outro lado, seria a face índia do Brasil recém-independente que viria a constituir a marca nacional, na busca de uma identidade que não se confundisse com a portuguesa. Mas, se Magalhães aproveita muito de O Uraguay, Alencar, nas Cartas sobre A Confederação, diz preferir o árcade, porque "apesar de viver no tempo das musas e dos sátiros, compreendeu melhor a vida selvagem" (Alencar, 1994b: 167).

Também Gonçalves Dias, poeta da primeira geração romântica, alcançara sucesso com temática semelhante à escolhida por Magalhães: eram os índios vítimas da colonização, de que nos fala David Treece ${ }^{11}$. E Herculano, que elogiara ${ }^{12}$ o poeta maranhense quando da publicação do Primeiros Cantos, em 1848, voltaria a fazê-lo, na carta dirigida a Pedro II: afinal, os índios-vítimas eram um assunto brasileiro ${ }^{13}$. Não foram, portanto, os contornos de vingança e repúdio aos portugueses que Magalhães imprimira a seu texto objeto de crítica do autor de Eurico, que, aliás, não chega a comentar, propriamente, o assunto do poema, embora diga que o "autor dos Tamoios" enganou-se quanto ao tema e lembre que "As epopeias verdadeiramente originais pertencem às ideias heroicas, aos gênesis das diversas civilizações." (Herculano, 1986: 216 e 213).

Alencar, que elogia também Gonçalves Dias, por várias vezes, nas Cartas dirigidas a Magalhães, diz esperar dele uma obra de mais vasta composição (certamente uma epopeia), para que se torne "o fundador" de "uma nova escola de poesia nacional" (Alencar, 1994b: 208). Não fala propriamente dos índios-vítimas, mas, ao que parece, poderia aceitá-lo ${ }^{14}$, pois aconselha Magalhães a abrir o

11 Para esse estudioso, há três momentos no indianismo romântico brasileiro: o do índio-vítima, o do índio-aliado e o do índio-rebelde. Cf. David Treece, Exiles, Allies, Rebels: Brazil's Indianist Movement, Indigenist Politics, and the Imperial Nation-State (Contributions in Latin American Studies, 16). Westport, Conecticut / London, Greenwood Press, 2000.

12 Embora fizesse observações a respeito da língua, da métrica e do estilo. Desculpava-as, porém, com a juventude do poeta e vaticinava: "o tempo apagará essas máculas; e ficarão as nobres inspirações estampadas nesse formoso livro [Primeiros Cantos]” (Herculano, 1986: 201).

13 "O que eu acho nos poetas da América, salvas algumas honrosas exceções, devidas principalmente a Gonçalves Dias, é a constante recordação da Europa” (Herculano, 1986: 216).

14 Embora, como se saiba, Alencar tenha procurado em seus romances mostrar a aliança entre portugueses e índios, o que fez que David Treece chamasse a dos índios-aliados essa fase do nosso Indianismo. 
poema pela confederação, explicando a seguir as suas causas, fazendo valer "o sentimento nacional, a liberdade, e o cativeiro dos índios" (Alencar, 1994b: 160). E, em meio às críticas tecidas, IG vai dando alguns contornos do assunto que o novo poema épico, por ele insistentemente referido, deva tomar:

o esboço histórico dessas raças extintas, o origem desses povos desconhecidos, as tradições primitivas dos indígenas, davam por si só matéria a um grande poema, que talvez um dia alguém apresente sem ruído, nem aparato, como modesto fruto de suas vigílias! [...] Se bem me lembro, em todas as epopeias que conheço [...] todos dão uma origem divina, ou ao menos heróica, ao povo que pretendem cantar (Alencar, 1994b: 159).

Se essas palavras de certa forma anunciam a publicação de O Guarani, num futuro breve, vêm também ao encontro das de Herculano acima referidas, pois era a gênese de uma nova raça que Alencar tinha em mente ao escrever o romance de Ceci e Peri e, depois, Iracema. O Guarani, que causou sucesso pelas façanhas do super-índio, ainda muito ligado ao modelo de amor entre mulher branca e homem de outra raça, fornecidos por Ferdinand Denis em Os Maxakalis, e mesmo por Victor Hugo no Bug Jargal, seria uma espécie de rascunho ${ }^{15}$ para a "lenda do Ceará", essa, sim, o poema épico nacional por que tanto se batera IG: o "primeiro brasileiro" seria filho de uma Iracema, nascida "além, muito além daquela serra que ainda azula no horizonte", em lugar de contornos não nítidos portanto, e em data ignorada, mas descendente de nobres e hospitaleiros tabajaras, "senhores das aldeias", e de Martim, verdadeiro herói de cavalaria medieval, que luta por sua dama, por seu rei, por seu Deus e, em nome deles, expulsa a raça invasora, os guaraciabas, a "raça dos cabelos de sol", funda uma cidade, impõe uma nova fé, uma nova língua, um novo chefe.

Nesse ponto, porém, há uma enorme discordância entre Herculano e Alencar: se este achava que uma nova civilização e uma nova raça nasciam da união entre o português e o índio, que o índio podia ser aliado do português (vejam-se

15 A esse respeito, consultar Maria Aparecida Ribeiro "A aurora e o crepúsculo: a recepção de Bug-Jargal e a questão racial no Brasil”, Culturas em Diálogo, Biblos, Rev. da Faculdade de Letras da U. de Coimbra, $\mathrm{n}^{\text {os }}$. I, 2003, p. 87-110; e "Projet et realization épiques chez José de Alencar", in Saulo Neiva (org.), Déclin E confins de l'épopée au XIX siècle, Tubingen, Gunter Narr Verlag, 2008, p. 189-214. 
os finais de O Guarani e de Iracema), Herculano, com a mente voltada para a ideia, citada anteriormente, de que os brasileiros eram os "portugueses na América", julgava que "os que traíram os interesses de sua gente e a religião de seus antepassados para se aliarem aos conquistadores, são, poeticamente considerados, uma completa negação da generosidade e do heroísmo da epopeia." (Herculano, 1986: 215).

Em perfeito acordo com o que Herculano haveria de dizer a Pedro II, em dezembro de 1856, quanto à falta de identidade entre brasileiros e índios, ficaram registradas no Diário do Rio de Janeiro, de 31/7/1856, essas palavras de Omega (possivelmente o escritor Pinheiro Guimarães como já se disse em nota anterior):

Quem são os heróis do Sr. Magalhães? São os Tamoios, isto é, uma tribo de selvagens, que tem apenas em comum com os brasileiros o terem outrora habitado uma parte do solo que estes agora ocupam. Diversos nas raças, na língua, na religião, e pelo seu estado de civilização, e como se isso ainda não bastasse, separados pelo ódio mais profundo e enraizado, e mais justificável por parte dos Tamoios, pois que, depois de terem sido despojados dos seus mais sagrados direitos pelos brasileiros, ou por seus pais, foram por estes completamente exterminados, não podem uns nunca ser, nem por um momento, confundidos com os outros. Entretanto quer-se dizer que o Sr. Magalhães, brasileiro, fez um poema patriótico, quando tomou por assunto de seus cantos os feitos de armas mais ou menos heroicos dos Tamoios, exercidos justamente contra os brasileiros, ou contra os seus ascendentes. (Omega, in Castello, 1953: 88).

\subsection{Os heróis e outros problemas}

Quando Alencar concorda, logo na primeira Carta, com a época de que é tirado o assunto de $A$ Confederação dos Tamoios, e a ele acrescenta que deveria ser realçado pela "grandeza da raça infeliz" e "pelas cenas da natureza esplêndida da nossa terra", diz também que o tema daria uma "divina epopeia se fosse escrito por Dante" (Alencar, 1994b: 157). As palavras de Herculano, embora recusando a forma épica, vão no mesmo sentido: para ele "os verdadeiros poetas do 
Brasil"16 deveriam "recolher as tradições, as relíquias poéticas das tribos índias". E, embora não ache que a poesia indígena seja popular, pensa que, representada "com fidelidade seria altamente literária" (Herculano, 1986: 215-216).

As observações de Alencar encerram ao mesmo tempo recomendação e crítica, como as do escritor português, e delineiam o tom programático e de insatisfação perante a falta de génio de Magalhães, por que todas as Cartas serão pautadas.

IG reclama dos descuidos com a metrificação e com a gramática, do abuso de hiatos e do desalinho da frase, "que muitas vezes ofende a eufonia e doçura da nossa língua" (Alencar, 1994b: 160), da repetição de elipses e de palavras - uma demonstração de falta de vocabulário — - da exploração seguida de uma mesma ideia já de si pobre, como é o caso da "tradição indígena que dava às águas do Rio Carioca o dom de tornar doce e melodiosa a voz daqueles que a bebiam" (Alencar, 1994b: 176). Chamam-lhe a atenção a falta de ligação entre o herói e a ação épica, a impropriedade dos símiles e das comparações, como, por exemplo, o da índia Iguaçu com um lírio ${ }^{17}$ (Alencar, 1994b: 176 e 192). Mas os símiles mais condenados são o que usam o guará e a andorinha como comparantes da liberdade. Porque Alencar até a sexta carta não os houvesse elogiado, achou um dos defensores de Magalhães que lhe devia chamar a atenção para a beleza de tal pintura. IG comenta, então, que "comparar a liberdade do Brasil com uma andorinha é ou "absoluta falta de imaginação" ou "desconhecimento da história natural brasileira" (cf. Alencar, 1994b: 209). O mesmo acontece com o guará, um pássaro "triste, merencório, amigo da solidão, do silêncio e do repouso": "pintar com ele a liberdade é o mesmo que exprimir a rapidez pela marcha da tartaruga" (Alencar, 1994b: 210). Se a comparação fosse em função da mudança das cores das penas, de escuras para escarlates, seria mais próprio, afirma Alencar, usá-la como símile do sangue da vingança dos índios contra a escravidão a que foram sujeitos.

Também Herculano, embora ressalvando sempre que não pode apreciar convenientemente a obra por não ser brasileiro, acaba por apontar defeitos de

16 Nesse passo da carta, Herculano ao escrever "verdadeiros poetas do Brasil", acrescenta, numa expressão que soa a ironia: "como é o autor dos Tamoyos".

17 Eis os versos: "[...] amava Aimbiré sua terna esposa como um lírio / prestes a abrir o cálice mimoso / aos beijos do colibri" (Magalhães, 1864: 195). 
estilo bastante significativos dos quais já havia falado Alencar. Começando por uma situação genérica, diz o missivista a Pedro II:

Há, todavia, coisas em que a crítica da Europa e da América têm de concordar. É acerca dos prosaísmos, das imperfeições de metro, das incorreções gramaticais. Às vezes, a colocação de um ou de mais versos duros ou frouxos entre outros cheios, harmoniosos ou suaves é um segredo de estilo; é uma sombra calculada para se obter um efeito de luz; mas longos períodos de versos ásperos ou lânguidos e até viciosamente metrificados, sem motivo nem vantagem, sinalefas violentas, hiatos mal-soantes, neologismos e solecismos são manchas, não só num poema como a Confederação dos Tamoios, mas também em qualquer pequena composição lírica. (Herculano, 1986: 219). ${ }^{18}$

Depois, o criador de Eurico acaba por descer ao pormenor e aponta situações concretas no poema de Magalhães, como também o fez Alencar. O mais curioso, porém, é que, ao observar a trivialidade das sentenças com que o "amigo do rei" orna o seu texto, o escritor português descobre a impropriedade de uma reflexão com que o autor da Confederação tenta lisonjear Pedro II, o que escapou — ou não foi do interesse - do criador de Iracema. "Soube ser cidadão, ser pai, ser homem, / Tendo nascido rei" - escreve Magalhães a respeito de Pedro I, pai do Imperador. Anota Herculano: "Sentença inexata e altamente injusta. Os reis não têm, que eu saiba, impedimento algum para serem bons cidadãos, bons pais, e bons homens" (Herculano, 1986: 220).

A Alencar parece fria a invocação feita ao sol n'A Confederação do Tamoios, embora pense que ela é "uma das mais felizes ideias que teve o Sr. Magalhães" (Alencar, 1994b: 201): o sol do Brasil "devia inspirar versos mais repassados de entusiasmo e de poesia"; o poeta "esboçou a imagem, porém não lhe modelou as formas" (Alencar, 1994b: 157 e 201). Além disso acha extravagante que "um poeta, destinando-se a cantar um assunto heroico, invoque para este fim o 'sol que esmalta as pétalas das flores', como faria um autor de bucólicas e de idílios"

18 Veja-se como essas palavras de Herculano concordam com as de Alencar: "O Sr. Magalhães [...] não escreveu versos; alinhou palavras, mediu sílabas, acentuou a língua portuguesa à sua maneira, criou uma infinidade de sons cacofônicos, e desfigurou de um modo incrível a sonora e doce filha dos romanos poetizada pelos "árabes e pelos godos" (Alencar, 1994b:188). 
(Alencar, 1994b: 198). O fato de invocar também os gênios pátrios origina ainda uma observação de IG:

o Sr. Magalhães não deu a menor atenção às tradições dos índios; Tupã, representado por um verdadeiro poeta, podia colocar-se a par do Theos de Hesíodo, de Júpiter de Homero, de Jeová de Milton; o princípio da divindade é sempre uma ideia grande e sublime, qualquer que seja a forma que lhe dê a imaginação humana (Alencar, 1994b: 208-209).

Herculano igualmente critica essa invocação: se por um lado pensa que o público brasileiro irá sorrir "ao ver repovoar a natureza de génios", por outro observa a impertinência de uma invocação ao sol, pois evocá-lo (repare-se: é evocar, não é invocar), assim como "os planetas, as estrelas remotas, o espaço infinito [...] cousas poéticas", resulta num "influxo físico que atua no nosso espírito, que desperta nele sentimentos e afetos", traz ao leitor a memória de "espetáculos belos ou sublimes" (Herculano, 1986: 217). Como Magalhães invoca, sem pintar o devido cenário que uma evocação proporcionaria, não obtém a emoção que eleva, mas, para Herculano, o grotesco que conduz ao ridículo. Aqui a crítica de IG é mais tênue: "sucedeu-lhe neste ponto [o da invocação ao sol] o mesmo que em quase todo o poema; esboçou a imagem, porém não lhe modelou as formas" (Alencar, 1994b: 201).

O nacionalismo de Alencar reclama da falta de "harmonia original nunca sonhada pela velha literatura de um velho mundo" (Alencar, 1994b: 158) do poema. Para o cearense, há tibieza na exploração das ideias e falta de dramaticidade; a apresentação da heroína é fraca e personagens historicamente importantes, como Anchieta e Nóbrega, são pouco exploradas (cf. Alencar, 1994b: 165 e 159).

Ele considera ter Magalhães evocado sombras heroicas do passado (como os dois jesuítas, Mem de Sá, Salvador Correia e Tibiriçá), tirando-lhes "o prestígio da tradição" e conservando-os no poema "nem mesmo na altura da história, quanto mais da epopeia". Julga ser Aimbiré um índio valente, "mas não [...] decerto um herói” (Alencar, 1994b: 189). Já para o escritor português, Aimbiré poderia ser um herói épico, mas "o autor dos Tamoios forcejou” ao delineá-lo (Herculano, 1986: 215).

Outro elemento várias vezes reclamado por IG é a ausência de uma heroína, de "uma Eva indiana", "uma virgem índia, de faces cor de jambo, de cabelos 
pretos e olhos negros, com o seu talhe esbelto como a haste de uma flor agreste, com suas formas ondulosas como a verde palma que se balança indolentemente ao sopro da brisa" (Alencar, 1994b: 172): a apresentação que Magalhães constrói para Iguaçu não faz adivinhar o seu protagonismo, "é uma mulher como outra qualquer" (Alencar, 1994b:173). Aliás, para Alencar, as virgens índias de Magalhães podiam "figurar num romance árabe, chinês ou europeu; se deixassem as penas de tucano [...] podiam vestir-se à moda em casa de Mme. Barat e Gudin e ir dançar a valsa no Casino e no clube de algum deputado" (Alencar, 1994b: 173).

Nem tudo são farpas, porém, quer na palavra do criador de Peri, quer na do de Eurico. Alencar elogia as estâncias que tratam da descrição do Amazonas, do luar que ilumina a praia de Iperoig, enquanto Anchieta escreve na areia os poemas à Virgem; a "narração cheia de força e colorido que faz Pindobuçu da morte de seu filho"; a resposta de Aimbiré ao jovem francês que lhe pede a filha por esposa; a pintura do velho guerreiro inspirado, que entoa o cântico de guerra a Tupã; a comparação que há, na prece de Iguaçu, ao despedir-se de Aimbiré (Alencar, 1994b: 159 e 175).

No entanto, o saldo é de que, no poema, "há confusão, anarquia, desordem e abundância de detalhes e situações insignificantes" (Alencar, 1994b: 164). Explicando melhor, diz o autor de O Guarani que Magalhães

nem conservou a simplicidade antiga, a simplicidade primitiva da arte grega; nem imitou o carácter plástico da poesia moderna: desprezando ao mesmo tempo a singeleza e o colorido, quis, às vezes tornar-se simples e fez-se árido, quis outras vezes ser descritivo e faltaram-lhe imagens (Alencar, 1994b: 181).

Herculano encontra, na Confederação, alguns "versos de beleza admirável", e cita como exemplo "Inda a alma de meu pai como um colibri / em fria noite etc." (Herculano, 1986: 216), trecho onde, por sinal, o autor de O Guarani, apesar de classificar como "lindíssimo" (Alencar, 1994b: 208), acha ter sido não só pouco explorado o mito indígena que vê nessa ave o mensageiro dos mortos, como também a própria palavra colibri, de que Magalhães abreviou "a última sílaba" (Alencar, 1994b: 208).

Embora o escritor português tenha opinião diferente da de Alencar no que diz respeito ao plano, que lhe pareceu "regularmente concebido", no que tange 
ao lineamento e aos carateres, que se lhe afiguram "em geral, bem distintos", o balanço que faz do poema de Magalhães assemelha-se ao do crítico brasileiro: o que falseia o poema épico sobre o qual Pedro II lhe pedira opinião "é a frialdade, a falta de crer e sentir, que lhe envolve os membros como um sudário" (Herculano, 1986: 217). Na parte narrativa, nas descrições, nos episódios, o que se encontra

é o poeta não inspirado, não impelido pelo terror ou pela cólera, não arrebatado pelo ardor religioso, não deixando cair sobre as cordas da cítara lágrimas de dor, de desesperança, ou de saudade, não errando pelos campos de batalha, e interrogando as ossadas dos guerreiros de Tupã ou de Cristo e as árvores seculares que os viram combater e cair; mas entregue a seu mister de poeta no gabinete de estudo [...] sem fé no assunto; sem fé nas simpatias do público por esse assunto, e forcejando por conquistá-las à força de empregar os meios artificiais que as escolas ensinam (Herculano, 1986: 217).

Chateaubriand como modelo a ser seguido pelos poetas americanos é outro ponto em comum entre Alencar e Herculano. Este cita os Natchez; o brasileiro transcreve trechos de diferentes obras do escritor francês cujas ideias, aliás, ecoam n'O Guarani e em Iracema ${ }^{19}$.

\section{O crítico romancista, o imperador ingênuo e o escritor diplomata}

No meio da polêmica, Pedro II, mascarado de "outro amigo do poeta", resolvera terçar armas pelo poema cuja edição — de luxo - patrocinara; melhor: em defesa da "criança raquítica e enfezada" (Omega, in Castello, 1953: 87) que vestira com veludo verde. As ideias que expôs mostram não só algumas contradições como ingenuidade.

O Imperador achava assunto nacional "livrar a pátria da escravidão imposta por outra raça" (Outro amigo do poeta in Castello, 1953: 95). Ora tal significava

19 A esse respeito ver, entre outros: Maria Cecília de Morais Pinto, A Vida Selvagem: paralelo entre Chateaubriand e Alencar, São Paulo, Annablume, 1995. 
ficar contra os portugueses, o que era incoerente em alguém que buscava conciliar raízes europeias e americanas, usando arminho e penas de tucano em seu manto.

Por outro lado... apesar de reconhecer defeitos de metrificação, diz "não ter encontrado nenhum verso errado"; apesar de concordar que Magalhães repete em seu poema a remissão à lenda sobre as águas do Carioca, defende a repetição, alegando que em todos os poemas há "imagens e pensamentos pelos quais os autores mostram até parcialidade" e que "os povos selvagens têm predileção por certas formas de pensamento". E como não pode concordar com a impossível cena da Confederação em que um índio arrebata com uma flechada o bico de um papagaio em pleno voo, resolve achar que seu autor merece mais aplausos que Basílio da Gama, pois, ao descrever um selvagem com sua aljava, acrescentou o adjetivo "grossa", "o que sempre quer dizer mais alguma coisa" (Outro amigo do poeta in Castello, 1953: 95 e 94). À "pequena censura" de IG de que os versos "[...] mas de novo estanques / Lágrimas brotam” contêm uma "inadvertência" (Alencar, 1994b: 175), o Imperador responde dizendo que estanques concorda com olhos e não com lágrimas. A mesma defesa impensada surge quando Alencar critica os versos "Que d'alma aos seios sobe": Pedro II lembra que os seios referidos "são os da alma, como tantos poetas já se têm exprimido" (Outro amigo do poeta in Castello, 1953: 97).

À observação do crítico cearense de que a comparação de Iguaçu com um lírio era imprópria, responde procurando fugir ao fato e à simbologia convencional do lírio e mesmo à imensa variedade de flores tipicamente brasileiras que poderiam substituí-lo, invocando a erudição, que lhe valeria uma das Farpas de Ramalho: "o poeta não compara diretamente a pessoa de Iguaçu com um lírio; e demais, não se encontram lírios sem ser brancos em nossas florestas? Porém eu não tenho a presunção de mostrar que aprendi alguma coisa de Botânica”.

O símile da andorinha com a liberdade, que recebeu os reparos de Alencar já aqui comentados, é considerado pertinente pelo "Outro amigo do poeta": "A andorinha é uma ave do Brasil, e o amor que ela mostra pelo seu ninho a torna, quando presa, uma imagem própria a representar a escravidão de um povo cheio de patriotismo." (Outro amigo do poeta, in Castello, 1953: 101 e 108).

No entanto, a réplica mais reveladora de que Pedro II era mesmo apenas amigo do poeta, ou de que entrava surdo no que constituía uma polêmica literária, é a 
que diz respeito à crítica feita por Alencar à invocação ao sol. Acha o Imperador que "invocar esse astro num poema cuja maior parte é devida aos prodígios da natureza brasileira" havia sido uma feliz lembrança. E, defendendo o amigo da acusação de que havia ainda, nos versos da invocação ${ }^{20}$, um inadequado bucolismo para um poema épico, explica que "não a admitirá quem sentir que não há em todas as concepções humanas [...] uma ideia que valha a florzinha agreste que nasce aí em qualquer canto da terra”. Mas vai além: acrescenta que "o adjetivo vário exprime a diversidade do colorido das flores" (como se vário concordasse com pétalos e não com sol) "e o outro, propício, a ação benéfica do sol que poderia só ter a de abrilhantar, dando o terceiro altos mais força à palavra prodígios" (Outro amigo do poeta, in Castello, 1953: 102).

Também quando IG acusa Magalhães de haver esgotado toda a inspiração quando descreve o Amazonas, nada restando para tratar do Paraná, a defesa do Outro amigo do poeta é de uma ingenuidade contundente: "o Paraná, na parte que limita o Brasil, havia necessariamente de ficar muito inferior na descrição ao rei dos rios" (Outro amigo do peta, in Castello, 1953: 94).

Ao fim da polêmica, Alencar publicaria O Guarani pondo em prática algumas das ideias que sugerira nas Cartas: o verso era substituído pela prosa; surgia um cenário grandioso para iniciar a narrativa; o índio era objeto de uma reabilitação e elevado à categoria de super-herói, um herói quase épico; suas lendas eram aproveitadas, seus costumes e seu vocabulário tinham espaço no texto; enfim, só faltava a heroína cor de jambo e a celebração do nascimento de um povo, que viriam com Iracema, oito anos mais tarde.

Herculano respondeu a Pedro II antes de Alencar pôr em prática suas ideias, mas depois de haverem sido publicadas todas as Cartas em torno do poema de Magalhães. Como não foi possível localizar a missiva que o imperador do Brasil enviou ao escritor português, fica-se sem saber se este lhe deu conhecimento da polêmica (e em que termos) ou se Herculano dela tomou conhecimento pelos jornais ou por algum outro meio. É que, coincidindo em muitos pontos a opinião de ambos os escritores, pode-se pensar que o autor de Eurico tivesse atenuado o seu julgamento, para não figurar do mesmo lado que IG. Pode-se também pensar,

20 Os versos, por inteiro, são assim: "Oh sol, astro propício que abrilhantas / do criado universo altos prodígios; / Que aos bosques dás verdor, doçura aos frutos, / e aos pétalos das flores vário esmaltas" (Magalhães, 1864: 11). 
pura e simplesmente, que, diante da ingenuidade de um imperador que lhe apresentava tal poema - e com patrocínio seu - Alexandre Herculano tivesse resolvido avisar a Pedro II, por via indireta, sem descer a pormenores e sem que suas palavras caíssem em domínio público, colocando mais achas na fogueira, que não era de continuar com tal mecenato. Assim, enquanto Alencar criticava o "amigo do rei" e o próprio "rei", o que acabaria por fazer ainda mais diretamente nas Cartas de Erasmo, começadas a publicar nove anos depois, Herculano, que já declarara sua admiração pelo Imperador, ao traçar o "Futuro Literário de Portugal e do Brasil" (1847), dava seguimento a um processo de aproximação que viria a culminar com uma visita de Pedro II à quinta de Val de Lobos.

\section{BIBLIOGRAFIA}

ALENCAR, José de (1994a) O Guarani, Coimbra, Almedina. (1994b) Iracema e Cartas sobre "A Confederação dos Tamoios", Coimbra, Almedina.

CASTEllo, José Aderaldo (1953) A Polémica sobre "A Confederação dos Tamoios", São Paulo, Faculdade de Filosofia, Ciências e Letras da Universidade de São Paulo.

CRISTÓVÃO, Fernando (1994) Diálogos da Casa e do Sobrado. Ensaios luso-brasileiros e outros, Lisboa, Cosmos.

DENIS, Ferdinand (1824) Scènes de la nature sous les tropiques, et de leur influence sur la poésie; suivies de Camoens et José Indio, Paris, Lecointe et Durey, Librairies.

(1826) Résumé de l'Histoire Littéraire du Portugal suivie du Résumé de l'Histoire Littéraire du Brésil, Paris, Lecointe et Durey, Librairies.

DIAS, Gonçalves (1959) Poesia Completa e Prosa Escolbida, Rio de Janeiro, Ed. José Aguilar.

HERCUlANO, Alexandre (1986) "Carta a Pedro II, Imperador do Brasil, sobre A Confederação dos Tamoyos por Gonçalves de Magalhães [...]" in Opúsculos V. Org., intr. e notas de Jorge Custódio e José Manuel Garcia, Lisboa, Presença, p. 212-221.

MAGALHÃES, Domingos José Gonçalves de (1864) A Confederação dos Tamoios, Coimbra, Imprensa Litterária.

, (1974) "Discurso sobre a história da literatura do Brasil", in Afrânio Coutinho, Caminhos do Pensamento Crítico 1, Rio de Janeiro, Ed. Americana-Prolivro. 